\title{
AWARENESS, ACTIONS, DRIVERS AND BARRIERS OF SUSTAINABLE CONSTRUCTION IN CHILE
}

\author{
Alfredo SERPELL ${ }^{\mathrm{a}}$, Jorge KORT ${ }^{\mathrm{b}}$, Sergio VERA ${ }^{\mathrm{c}}$ \\ a, b, Department of Construction Engineering and Management, School of Engineering, \\ Pontificia Universidad Católica de Chile, RM 7820436 Santiago, Chile \\ ${ }^{\circ}$ Center for Sustainable Urban Development (CEDEUS), Pontificia Universidad Católica de Chile, \\ Santiago, Chile
}

Received 03 October 2011; accepted 21 January 2012

\begin{abstract}
The socio-economic conditions of a country and the overall practices of the construction industry towards Sustainable Construction (SC) are critical factors to define the foundations for developing and carrying out a strategic plan to advance in sustainable construction. This paper reports the results of a study about SC practices currently implemented by construction companies and discusses the level of awareness and knowledge, barriers and drivers of SC that were found in building and infrastructure construction companies. In addition, it analyses the influence of the company size on SC practices. Research results show that Chilean construction firms are in an early stage of the path for achieving SC. Their practices towards SC are highly dependent of the company's size and its core business. Main barriers towards SC are the lack of financial incentives, lack of integrated design, and affordability whereas company's tax reduction incentives related to the level of investment effort on SC would be a key governmental policy to promote sustainability. The results of this study might be particularly useful for other countries, particularly developing ones, and for government policy making.
\end{abstract}

Keywords: sustainable construction, construction firms' practices, drivers of change, barriers, policy and regulations, survey.

Reference to this paper should be made as follows: Serpell, A.; Kort, J.; Vera, S. 2013. Awareness, actions, drivers and barriers of sustainable construction in Chile, Technological and Economic Development of Economy 19(2): 272-288.

JEL classification: $\mathrm{L} 7, \mathrm{O} 1, \mathrm{O} 2$.

Corresponding author Sergio Vera

E-mail: svera@ing.puc.cl 


\section{Introduction}

The construction industry is a key sector for sustainable development because of its socio-economic and environmental impact. The construction industry influences the socio-economic development in four main ways (Ofori 2007).

- It builds the infrastructure and productive facilities. This contribution is more significant in developing countries due to the high demand for infrastructure, buildings and housing. Thus, the construction industry strongly supports their economic and social developments that turn into prosperity, social equalization and minimum standards of living (Gomes, Silva 2005).

- It contributes to the Gross Domestic Product (GDP). The contribution to GDP is usually higher (in percentage) in developing countries than that in high-income countries (John et al. 2001; Gomes, Silva 2005). For example, the building sector contributes to $14 \%$ of Brazil's GDP while it only contributes to $11 \%$ of the European Union GDP (John 2000).

- It provides direct employment to 110 million people worldwide. In developing countries, the construction industry is labour-intensive due to lack of technology, workers' low skills and knowledge, and lower salaries.

- Construction products are spread throughout the country, and collaborated to develop entrepreneurship and transfer technology to all citizens of the country (Turin 1973).

The environmental impacts of the construction industry are also significant. Worldwide, this industry is responsible for the consumption of $40 \%$ of total energy production, $40 \%$ of raw materials and $25 \%$ of timber; the use of $16 \%$ of water; the generation of $30-40 \%$ of solid waste and 35-40\% of CO2 emissions (Son et al. 2011; Van Bueren, De Jong 2007; Akbiyikli et al. 2012; Berardi 2013).

Sustainable construction (SC) was defined by Agenda 21 for Sustainable Construction in Developing Countries (SCDC) as "a holistic process aiming to restore and maintain harmony between the natural and built environments, and create settlements that affirm human dignity and encourage economic equity" (Du Plessis 2002). This definition implies that the initial approaches, more related to technical issues, do not ensure a sustainable development whereas economic and social aspects of sustainability (non-technical issues) would not be considered (Shafii et al. 2006, Du Plessis 2007). Technical issues of sustainability such as the efficient use of resources (e.g. energy, water) and the prevention and reduction of environmental impacts of materials, buildings components and construction technologies, are essential parts of sustainable construction. However, opposite to what happens in developed countries, the degree of achievement of technical issues is low and under development in most of developing countries. For instance, building energy codes do not exist in many developing countries making it difficult to save energy during the life cycle of buildings. Therefore, the achievement of SC in developing countries is complex and challenging not only because their social and economic conditions may be difficult but also because technical issues are still unsolved.

The construction industry involves many parties that need to be responsible for SC during the whole process, from planning to the deconstruction phase (Dahl et al. 2005). Main stakeholders of the construction industry are clients, material's manufacturers, developers, designers or consultants, constructors, research institutions, governmental offices and regulatory bodies. 
The achievement of SC may require different approaches among developing countries according to their specific socio-economic situation and the level of development of their construction industry. For this reason, the Agenda 21 for SCDC showed an overall strategy for addressing the challenges involved in the implementation of sustainable construction (Du Plessis 2002). However, there is a conflict here. On one side, construction firms need to be viable businesses and, on the other hand, studies have revealed the perception that sustainable construction projects such as buildings cost more than conventional buildings (Yudelson 2009; Robichaud, Anantatmula 2011). This scenario is not a fertile soil to let the decision of going sustainable to the construction firms. It might be necessary to understand what could motivate these companies towards sustainability, and how to overcome barriers that are making it difficult for them to follow the path to SC.

Zainul-Abidin (2010) proposed a path for achieving sustainable construction, which involves many stakeholders (government, developers, clients, buyers/end users, contractors, consultants, manufacturers/suppliers, others). This path starts with the awareness, interest and knowledge on SC as essential elements to reach SC. However, in many developing countries the lack of awareness on SC projects might be the rule among stakeholders. This situation may reduce the motivation of construction firms to implement SC practices. In Chile, there is a lack of information about what would motivate construction firms towards sustainable construction.

The socio-economic situation in each developing country and the overall construction industry practices towards SC define the foundations to develop and carry out a strategic plan to achieve SC. These foundations are different among countries; thus, the diagnosis of the current scenario of both the country and its construction industry is needed. At regional level, several studies have assessed the socio-economic situations and construction industry practices. In Latin America and the Caribbean (LAC) it has been reported that sustainability is not a part of the mainstream business and that SC is not a priority (John et al. 2001; Gomes, Silva 2005). Also, it has been found that the major barrier to SC is the perception of higher costs, thus governments need to generate a policy framework as well as provide financial incentives to boost SC implementation. For instance, Lorenz et al. (2005) analysed the situation in Central/Eastern Europe and identified actions and future strategies that would help promote and achieve SC. Similarly, Gomes and Silva (2005) also found that the government rather than the market must be the driver for sustainable development because construction firms might focus on quantitative delivery without considering life-cycle assessment. Shafii et al. (2006) evaluated the construction industry attitudes for sustainable development in the Southeast Asia region and discussed the barriers to implement SC and provided recommendations to drive SC. They found that main barriers to SC are lack of awareness, lack of education on sustainable design and construction, perception of higher cost of sustainable buildings, low-prices due to hard-bid processes, lack of regulatory frameworks to encourage SC and lack of professional capabilities, among others.

On the other hand, the commitment of all stakeholders is mandatory to achieve SC. Since the large variety of actors and the complexity of their interactions, studies have diagnosed and evaluated the practices towards SC of stakeholders and have identified drivers and barriers from the point of view of these actors. Myers (2005) reviewed the practices to sustainability of 
the main construction companies in UK based on public disclosures made by these companies and concluded that remarkably few construction companies embrace sustainability, and relatively few companies have changed their business paradigms. Manoliadis et al. (2006) carried out a study to identify the main drivers of change towards SC in Greece applying a questionnaire to 20 experts of the industry, such as consultant engineers, construction managers and contractors and found that main drivers of SC were energy and resource conservation, land use regulations and urban planning policies. Also, based on a survey, Majdalani et al. (2006) studied the role played by owners, developers, architects, engineers, and contractors in the sustainable development in Lebanon. The main conclusions pointed out that architects and engineers were the most aware actors regarding sustainability, while Lebanese construction companies showed a low level of implementation of sustainable practices. Moreover, owners and developers showed reasonable awareness about SC and supported SC initiatives as long as these practices would not cause additional costs and risks. Son et al. (2011) applied a survey to contractors in US and Korea to evaluate their concerns on SC practices that could be carried out during the construction phase and their level of preparedness for SC. Their study revealed that the level of awareness and preparedness for SC among constructors was high. However, in the design state of the construction project, contractors should be involved to exploit their knowledge. They concluded that fiscal incentives and regulations promoted SC, while affordability was the chief barrier that prevented it. In Malaysia, Zainul-Abidin (2010) conducted a study, based on surveys and interviews of project developers, to investigate their level of awareness and knowledge of SC practices. She found that only large developers were starting to implement SC concepts in their projects, while many others were reluctant and uncertain to apply these concepts due to lack of knowledge and concerns on costs. Shen et al. (2010) studied 87 projects' feasibility study reports in China to evaluate their performance in terms of economic, social and environmental attributes. They found that the economic attributes were the most salient concern in the current practices of project feasibility studies, and much less attention was given to the socio-economic performance.

The literature review, first, shows that, from the country perspective, the situation in developing countries located in LAC, South East Asia, Central/Eastern Europe is quite similar with needs for education and training, capacities, technologies, and policies to develop and implement SC, which lack make SC difficult to achieve. Second, literature review shows that: the level of awareness of construction firms vary among countries; the level of implementation of SC practices is low even in industrialized countries; lack of regulatory frameworks; construction projects' performance evaluation is based on its economic attributes only and affordability are the main barriers to SC. Also, regulations and policies are the main SC'drivers. Third, Du Plessis (2007) and Zainul-Abidin (2010) showed that the path to achieve SC is long and involves many stakeholders, but the starting point is to know the current situation in each country. Although previous studies shows similarities among different regions worldwide, diagnosis of the current situation in each country is needed to take into account its particular socio-economic-politic situation and practices of the construction industry.

Therefore, the aim of this paper is to present the results of the diagnosis about overall practices of construction firms towards SC in Chile. This study focuses on identifying current SC practices implemented by construction firms, the level of awareness of these companies, 
barriers that are preventing SC and drivers that would motivate the implementation of SC practices. In contrast to studies reviewed above, this paper not only addresses the building sector but also the infrastructure sector and analyses the influence of the company size on SC practices. Although the paper deals with the three angles of SC - social, economy and environment - the main focus is on environmental sustainability.

\section{Chile's construction industry and the government's role}

Chile is a developing country located in South America that joined the Organisation for Economic Co-operation and Development (OECD) in 2010. Chile is qualified as an upper-middle income country by the World Bank (GDP per capita PPP is around USD\$14,500 and population is around 17 million). The construction industry is one of the main domestic industries and contributes to $13 \%$ of GDP and directly employs about $10 \%$ of the labour force.

At the beginning of 1990s, strong environmental concern rose in Chile, and new laws and regulations were promulgated. The most notable among these was the Environmental Basis Law 1993, which covers the procedures for obtaining environmental authorization for new projects through the Environmental Impact Assessment System (EIAS) (Newbold 2006). EIAS only applies to large public and private construction projects; thus, in practice, most of the buildings are not subject to the EIAS (Serpell, Kort 2006).

The Chilean Chamber of Construction signed the Clean Production Agreement (CPA) in 2000. The CPA looked to promote SC practices such as a reduction of dust emissions in construction sites and during transportation of soils, aggregates and construction waste materials; management of solid waste materials including the promotion of the recycling business; and the mitigation of the noise caused by construction activities. Construction companies individually and voluntary agreed to build according to sustainable practices indicated in the CPA, agreement that also included goals, financial incentives and penalties for construction companies that has subscribed to the agreement. Fifty one construction companies of the Metropolitan Region first signed the CPA in the year 2000, and several other regions have joined this initiative afterwards.

In Chile, there are two main governmental offices related to the construction industry, the Ministry of Public Works and the Ministry of Housing and Urban Development. Serpell and Kort (2006) evaluated the performance of these Ministries regarding SC. They concluded that environmental awareness is low. In particular, they found a lack of concern and knowledge on environmental issues and sustainable building practices in the Ministry of Housing and Urban Development. The diagnosis was slightly better in the Ministry of Public Works, which created the Environmental Administration Office, and promoted the design and construction of demonstration projects (e.g. schools with energy efficiency strategies).

It seems that the main dilemma of the construction industry is to balance the economic sustainability of companies with the environmental protection and, at the same time, contribute to the social and economic well-being of people. To carry out this challenge, construction industry's actors must cooperate to implement SC practices; however, the level of commitment of these actors to implement SC practices is uncertain. Therefore, this paper aims to shed light on the current role played by construction firms. 


\section{Methodology of the study}

The study was carried out through the application of survey questionnaires distributed among a number of construction companies. Survey research by means of questionnaires is a research method that provides a numeric description of trends, attitudes and opinions of a population by studying a sample of the population being the subject of the study (Creswell 2013). In this case, building and infrastructure construction companies with headquarters located in the Metropolitan Region of Chilean capital comprised the population.

Surveys were sent to top managers of construction firms because they have an overall knowledge of their companies and are able to define strategic actions within the company. In total, 41 valid surveys were responded; they were distributed according to the company's size and core business as shown in Table 1.

Table 1. Number of construction companies that responded the survey according to their annual gross revenue and core business

\begin{tabular}{cccc}
\hline Annual Gross Revenue (millions of US\$) & Building & Infrastructure & Building and Infrastructure \\
\hline$<5$ & 8 & 2 & 2 \\
\hline 5 to 10 & 14 & 0 & 1 \\
\hline$>10$ & 7 & 4 & 3 \\
\hline Total number of companies & 29 & 6 & 6 \\
\hline
\end{tabular}

The survey had 5 sections and 21 question in total. Data related to 6 of these questions, which are shown in the appendix, are analysed in this paper. Three types of closed questions were used in the questionnaire: (1) questions with a Likert scale of 5 intervals $(0 \%, 25 \%, 50 \%$, $75 \%$ and $100 \%$ ) to measure the importance level; (2) Yes or No questions used to evaluate the existence or absence of some aspects; and (3) questions dealing with priority assignation.

\section{Results and discussion}

\subsection{Awareness, knowledge and interest of stakeholder on SC}

Every construction industry stakeholder is crucial to embark this industry on the path to SC. According to Zainul-Abidin (2010), awareness is the starting point of the path to achieve SC while knowledge is crucial to move from awareness to implementation of SC practices. In the study, construction firms were asked to evaluate their level of awareness about their own environmental practices and the level of knowledge of several construction stakeholders about some SC practices.

Tables 2 and 3 show the level of awareness of construction firms classified by company size and company core business, respectively. It is clear that larger companies and those that work in the infrastructure construction sector are more aware about environmental protection. 
Table 2. Level of awareness on environmental sustainability of construction companies according to company size

\begin{tabular}{cc}
\hline Annual Gross Revenue (millions of US\$) & Level of awareness (\%) \\
\hline$<5$ & 56.3 \\
\hline 5 to 10 & 56.7 \\
\hline$>10$ & 71.4 \\
\hline
\end{tabular}

Table 3. Level of awareness on environmental sustainability of construction companies according company core business

\begin{tabular}{lc}
\hline \multicolumn{1}{c}{ Company core business } & Level of awareness (\%) \\
\hline Building & 58.6 \\
\hline Infrastructure & 79.2 \\
\hline Building \& Infrastructure & 58.3 \\
\hline
\end{tabular}

Fig 1(a) shows the level of knowledge on SC of different stakeholders perceived by construction firms. Overall, lack of knowledge about SC is common among all stakeholders. First, it is noticeable the unusually low level of knowledge of the building sector, which agrees well with the low level of awareness of this sector. Owners and designers of infrastructure projects are significantly more knowledgeable than those that work in building projects. Their knowledge is crucial to implement SC practices because owners define the goals of the project such as the level of sustainability, whereas designers overturn these goals in the project via construction documents and drawings. On the contrary, developers are perceived as the least knowledgeable in both building and infrastructure sectors. This fact limits extremely the achievement of SC because developers are in charge of relevant projects (i.e. real estate).

Also, contractors were asked how they perceive the interest on SC of different stakeholders. Results are shown in Fig. 1b. Similarly to previous results, large differences exist between building and infrastructure construction firms. Low interest on SC is found among all building sector stakeholders, while owners and designers of infrastructure projects are significantly more interested on SC, a fact that could be related to their high level of awareness and knowledge.

a)

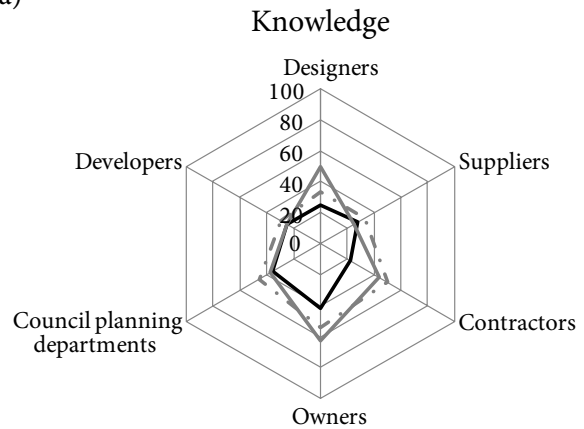

b)

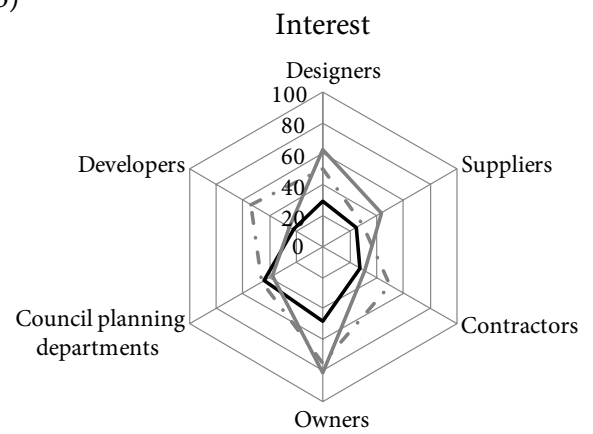

Building Infrastructure _ - - Building \& Infrastructure

Fig. 1. Levels of: a) knowledge and b) interest of stakeholders, as perceived by construction firms 


\subsection{Actions}

Since the aim of this study was to carry out the overall diagnosis of SC by constructions firms, it is crucial to identify the SC practices implemented by construction companies during the construction works in both buildings and infrastructures projects. This allows to get the starting point to follow a path to achieve SC. Firms were asked about the percentage of projects in which actions have been implemented to reduce or prevent environmental impacts of construction works. Table 4 ranks the SC actions by their frequency of implementation on-site. Overall, the most frequent actions applied on-site are related to materials' waste management and the reduction of dust emissions, while the reduction of chemical liquids and materials and the energy use rank lower. This result might show the influence of the CPA. Since the CPA promotes control/prevention of materials' waste and dust emissions, these SC actions ranked higher in the survey. This evidences the significant and crucial impact that governmental policies - even those voluntarily signed - can have in prompting the application of SC practices.

Table 4. The percentage of projects where SC actions have been implemented on-site to reduce or prevent the environmental impacts of construction works

\begin{tabular}{lcc}
\hline \multicolumn{1}{c}{ Reduction/prevention of } & Projects where SC actions have been implemented (\%) & Rank \\
\hline Solid waste materials & 75.0 & 1 \\
\hline Dust emissions & 68.9 & 2 \\
\hline Danger materials' waste & 57.4 & 3 \\
\hline Water use & 57.1 & 4 \\
\hline Noise & 50.0 & 5 \\
\hline Chemical liquids and materials & 44.1 & 6 \\
\hline Energy use & 43.0 & 7 \\
\hline
\end{tabular}

Fig. 2 shows the results of Table 4 grouped according to the companies' annual gross revenue and core business. It can be observed in Fig. 2a that larger companies (Annual Gross Revenue > USD \$ 10 million) implement SC practices on construction sites more frequently. This result could be due to:

- Larger companies are more aware about sustainability; this was already shown in section 3.1 ; and

- Clients of larger projects are more aware of environmental impacts demanding more sustainable projects. Question 4 (see Appendix) of the survey was used to find out if this possible cause is true. Pearson's correlation coefficient was used to evaluate the correlation between the company size and the client demand for more sustainable projects. Pearson' coefficient of 0.78 (level of confidence above 95\%) shows the existence of a positive and significant correlation. This result strongly evidences the key role clients played to trigger the implementation of SC practices.

Fig. 2(b) also shows that companies of the infrastructure sector apply SC practices in more projects than building companies. This result could be explained by three factors acting together: 
a)

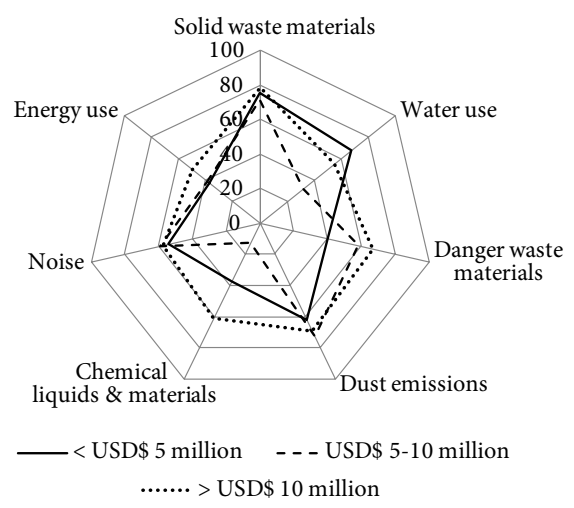

b)

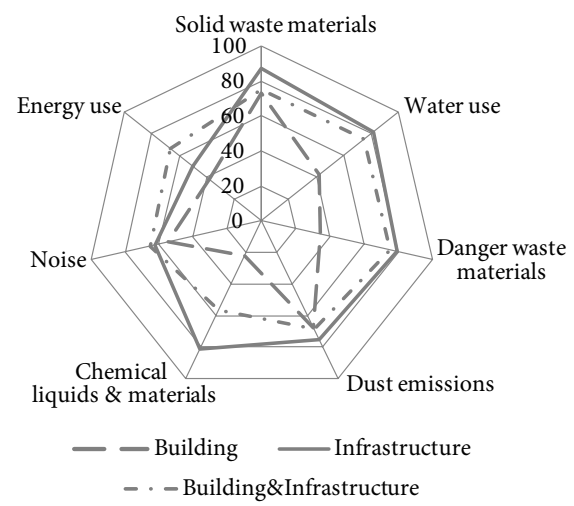

Fig. 2. Percentage of projects in which SC actions have been implemented in the last three years, grouped by a) companies' annual gross revenue, and b) companies' core business

- Infrastructure projects are usually built by larger companies, which apply SC practices more frequently as shown in Fig. 2(a);

- The Ministry of Public Works, which is one of the greatest clients demanding infrastructure projects, is interested on SC and in demanding sustainable projects; and

- Infrastructure projects are subject to EIAS due to their magnitude, while most of building projects do not require EIAS because of their smaller size.

\subsection{Drivers of change and financial incentives}

\subsubsection{Drivers of change}

The literature review shows that the role of the government is recognized to be the key factor to promote SC (Tan et al. 2011; Shi et al. 2013). Nevertheless, there are other drivers of change that could have similar relevance. Identifying these drivers of change is crucial to understand what motivates construction companies to implement SC actions. Therefore, Q4 asked about the factors that have promoted the implementation of the SC practices in construction projects.

The results of Q4 are shown in Fig. 3. In agreement with other studies (Lorenz et al. 2005; Gomes, Silva 2005; Pitt et al. 2009; Shen et al. 2010; Zainul-Abidin 2010), regulations are the main drivers to enforce the implementation of SC actions. Company's awareness is also one of the main drivers that have promoted the implementation of SC practices. This means that companies have advanced from a starting point focused on awareness towards implementation, which involves commitment with SC. Nevertheless, section 3.1 shows that some SC practices present low level of implementation, thus awareness and commitment are not enough to drive more significant changes. This situation could be caused by the lack of knowledge on SC technologies, lack of regulations to enforce the implementation of more SC actions, lack of client demand for sustainable projects, and concern about costs. 
Fig. 3 also reveals that Chilean construction companies consider sustainability as a key element of their corporate image; thus, companies would need to promote what they do in terms of sustainability. This also contributes to differentiate the company among others that have done little in terms of sustainability, which could turn in higher sales. This fact evidences the link between construction practices and competitiveness of construction companies (Tan et al. 2011).

Also, it was found that the level of influence of drivers on promoting SC varies significantly according to both companies' size and core business as shown in Fig. 4. It is noticeable that regulations, corporate image and client demand have much stronger influence encouraging large companies to implement SC actions, whereas their level of influence decrease significantly as the company size decreases (Fig. 4(a)). In agreement with the results of section 3.2, Fig. 4(b) shows that clients play a crucial role demanding SC infrastructure projects, whereas the clients seem to have much lower requirements of sustainability for building projects. This is not surprising because private and public owners of large infrastructure projects are more aware about sustainable developments, as shown in section 3.1. Fig. 4(b) also shows

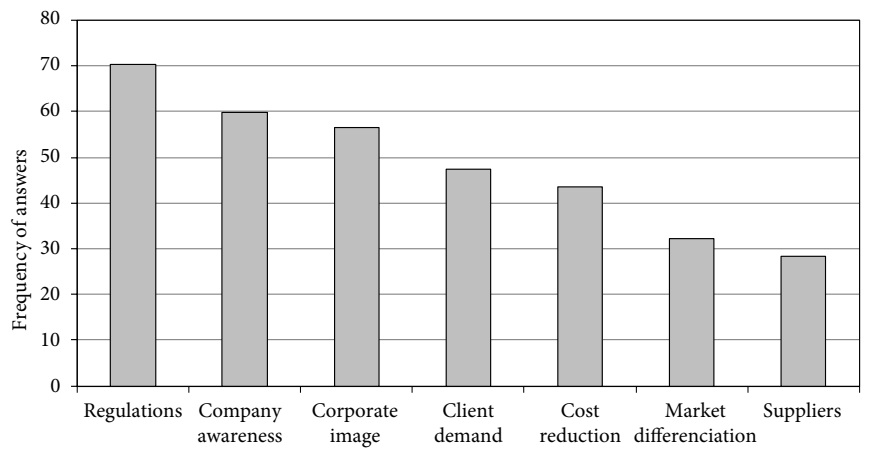

Fig. 3. Drivers which promote SC practices among Chilean Construction companies

a)

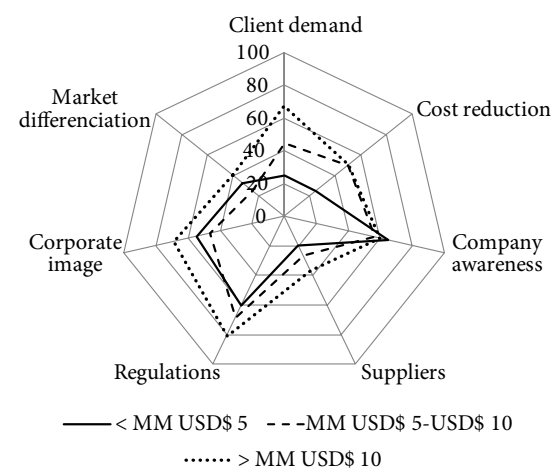

b)

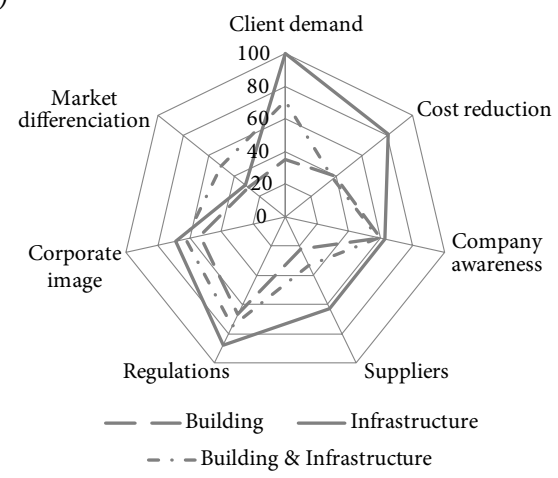

Fig. 4. Drivers of change grouped by two factors: a) companies' annual gross revenue, b) companies' core business 
surprising results, as it is that companies of the infrastructure sector indicate that the implementation of SC practices has been motivated by cost savings, while literature shows that concerns about costs is the main barrier that prevent SC (e.g. Pitt et al. 2009). At this time, there is no clear evidence on what savings are being obtained by infrastructure companies, and more studies are needed about this issue.

\subsubsection{Financial incentives}

The survey did not ask for financial incentives as a driver of change because, nowadays, this category of SC incentive is not available in Chile. Moreover, most building projects are not subject to EIAS. In consequence, construction companies of the building sector were additionally asked about what financial incentives would promote SC. The following four types of economic benefits were included in the survey:

- Tax reduction according to the level of investment in SC made by the company;

- Subvention of certified sustainable products;

- Increment of the maximum built surface established by council planning departments for buildings and housing; and

- Property tax reduction of buildings built with SC practices.

The first three financial incentives are direct benefits to the construction companies. However, these benefits can be transferred to the owners by selling apartments and houses at a lower price than those built without SC practices. The property tax reduction is a direct economic benefit for the owners or users that could also increase client demand for sustainable building projects.

Fig. 5 shows that the most voted financial incentive corresponds to the tax reduction for the construction company with $51 \%$ of the votes, while the other incentives are not seen as effective. This shows that only specific financial incentives are preferred by construction companies. Then governmental offices should only focus on those incentives that could be better accepted and implemented by the construction industry, which would turn in larger impacts of financial incentives towards SC.

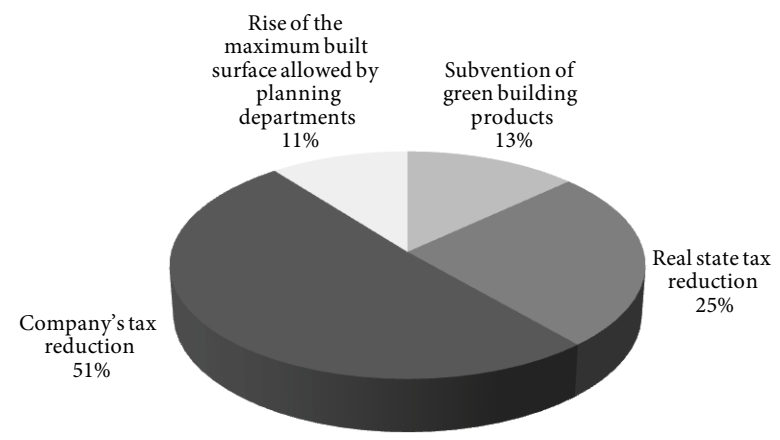

Fig. 5. Financial incentives that would promote the implementation of SC practices in building construction firms 


\subsection{Barriers}

Few studies have focused on studying the barriers for implementing SC and a large variety of factors are usually considered as barriers. Barriers can be associated to the overall socio-economic situation of developing countries. For instance, most developing countries are significantly marked by poverty and economic problems and it is difficult to establish the environmental protection as a national priority.

In the survey, a question about national socio-economic and construction industry barriers was included to identify potential barriers for implementing SC. Barriers were grouped into 4 categories (knowledge, economic/market, institutional and governmental), and each category included barriers. Fig. 6 shows the two most voted barriers for each category. Overall, several barriers ranked high.

Lack of financial incentives to promote the implementation of SC practices, the lack of integration of designers with other stakeholders to develop sustainable projects (integrated design), and economic needs of higher priority appear as the three main barriers. Implementation of financial incentives, as the reduction of company taxes according to the investment on SC, seems to be a key policy to promote SC. The fact that construction projects are conceived without the integration of all stakeholders is a current practice in Chile that significantly restricts the opportunities to implement sustainable practices. This is not only because the lack of environmental concern, knowledge and regulations, but also because traditional project management is not adequate to deal with the dynamics and complexity of decision-making processes that involve many actors, such as planners, developers, architects, engineers, contractors, etc. (Bresnen et al. 2005). Also, sustainability is not seen as a priority. For instance, social housing deficit in Chile was enormous for several decades. National policies in the ' 90 pointed out to build a large number of houses in a short time and at a low cost. Under this scenario, social and environmental sustainability as well as quality were not a priority.

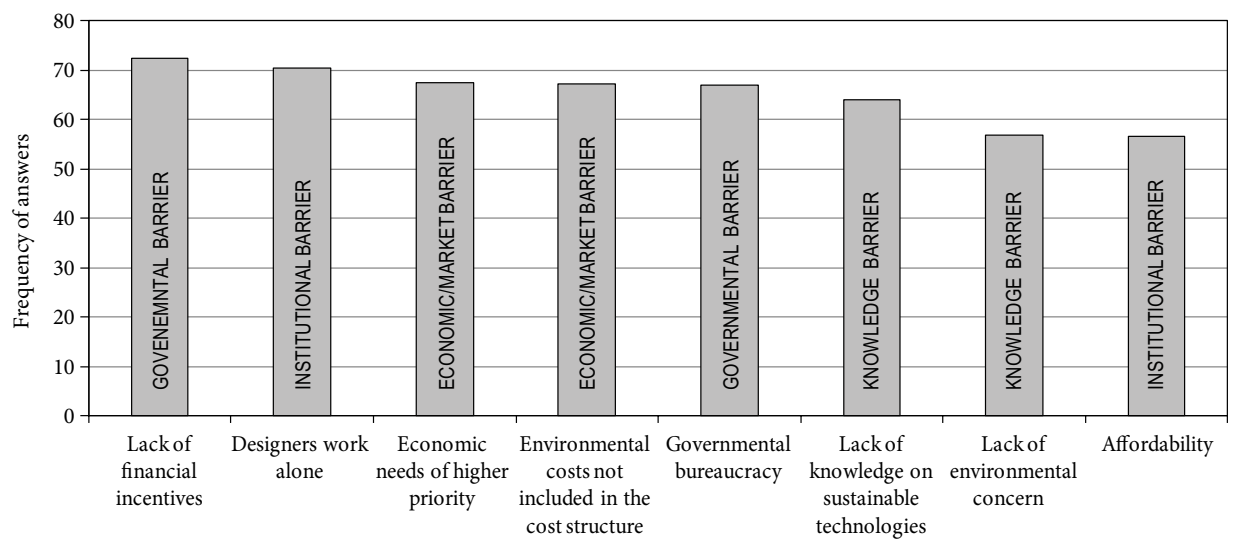

Fig. 6. Main two barriers per category 
Fig. 6 also shows that affordability is not seen as the main barrier as other studies have found (Pitt et al. 2009; Majdalani et al. 2006). Nevertheless, construction companies are concerned about additional costs of implementing SC practices. As a consequence, this result could be originated because other aspects are seen as more restrictive in the current immature stage of SC implementation in Chile.

\section{Conclusions}

The study presented in this paper identified the level of SC awareness of construction firms, the level of SC knowledge and interest of different stakeholders of construction projects, actions implemented on construction work-sites, drivers that promote and barriers that prevent SC. In contrast to the studies found in the literature review, this paper includes a comparison of what occurs in the infrastructure and building sector, and an analysis of the influence of companies' size.

Overally, the study shows that the Chilean construction industry is at the initial stage of the path to SC. In addition, the low level of implementation of SC practices in construction works and the lack of regulations/policies show that much more should be done to shift the traditional construction processes towards SC.

This study also revealed that construction companies' practices towards sustainability are highly dependent on the company's size and their core business. Results show that larger and infrastructure companies implement SC actions more frequently than building companies. This is a consequence of larger client demand for sustainable projects and higher awareness of large and infrastructure companies. This agrees well with the fact that owners and designers of infrastructure projects are seen by contractors as knowledgeable and interested on SC, while they have a low level of knowledge and interest on SC in the building sector. This is a severe averse scenario for achieving SC in the building construction sector. There are needs for owners' and developers' education, the generation of regulations and policies to enforce the implementation of SC practices, and the implementation of financial incentives for sustainable projects to reduce owners' aversion to risk-taking.

Client demands and regulations are recognized as the main driver of change by Chilean construction companies. However, governmental regulations and policies are scarce, and Ministries related to the construction industry need to play a more active role in creating and promoting regulations and policies for the sector. Currently, no governmental, financial incentives exist for sustainable projects. These studies have shown that financial incentives could be well received and drive changes towards SC. The paper shows that company's tax reduction according to the level of investment in SC is a key policy to promote SC among construction firms. This supports the crucial role of the countries' government to enforce (via policies/regulations) and stimulate (via financial incentives) the implementation of more sustainable practices by construction firms and other industry stakeholders.

Finally, several barriers that prevent SC implementation rank high. One of the main barriers is the lack of integrated design. This situation does not allow the participation of stakeholders and decision-makers from the very start of projects. This scenario mainly occurs in building construction projects, where designers do not act together to improve the whole 
project and contractors are only involved in the construction phase. Although affordability is not seen among construction companies as a main barrier to achieve sustainability, the mission of all companies is to generate profits. The implementation of SC practices within the company needs to be recognized as an opportunity to create value. Here, more research is needed to evaluate the economic impacts of SC actions (technical and processes) implemented on construction sites thus construction companies are well informed about those practices that will balance environmental protection and costs properly.

\section{Acknowledgements}

This work was supported by project grant CONICYT/FONDAP 15110020.

\section{References}

Akbiyikli, R.; Eaton, D.; Dikmen, S. U. 2012. Achieving sustainable construction within private finance initiative (PFI) road projects in the UK, Technological and Economic Development of Economy 18(2): 207-229. http://dx.doi.org/10.3846/20294913.2012.677586

Berardi, U. 2013. Clarifying the new interpretations of the concept of sustainable building, Sustainable Cities and Society 8: 72-78. http://dx.doi.org/10.1016/j.scs.2013.01.008

Bresnen, M.; Goussevskaia, A.; Swan, J. 2005. Implementing change in construction project organizations: exploring the interplay between structure and agency, Building Research \& Information 33: 547-560. http://dx.doi.org/10.1080/09613210500288837

Creswell, J. H. 2013. Research design: qualitative, quantitative, and mixed methods approaches. London: Sage Publications, Inc.

Dahl, P.; Horman, M.; Pulaski, M.; Pohlman, T. 2005. Evaluating design-build-operate-maintain delivery as a tool for sustainability, in Construction Research Congress, 2005, San Diego, California, United States, $1-10$.

Du Plessis, C. 2002. Agenda 21 for sustainable construction in developing countries. CSIR Report BOU/ E0204, CSIR, UNEP-IETC, Pretoria.

Du Plessis, C. 2007. A strategic framework for sustainable construction in developing countries, Construction Management and Economics 25: 67-76. http://dx.doi.org/10.1080/01446190600601313

Gomes, V.; Silva, M. G. D. 2005. Exploring sustainable construction: implications from Latin America, Building Research \& Information 33: 428-440. http://dx.doi.org/10.1080/09613210500218891

John, V. M. 2000. Recycling of wastes in construction: a contribution to the methodology for reserach and development. Escola Politécnica, USP.

John, V. M.; Agopyan, V.; Sjostrom, C. 2001. An agenda 21 for Latin American and Caribbean construbusiness. A perspective from Brazil. Agenda 21 for Sustainable Construction in Developing Countries - First Discussion Document [online], [cited 3 May 2013]. Available from Internet: http://www.irbnet.de/daten/iconda/CIB663.pdf

Lorenz, D.; Lützkendorf, T.; Panek, A. 2005. Sustainable construction in Central/Eastern Europe: implications from SB04 in Warsaw, Building Research \& Information 33: 416-427. http://dx.doi.org/10.1080/09613210500219089

Majdalani, Z.; Ajam, M.; Mezher, T. 2006. Sustainability in the construction industry: a Lebanese case study, Construction Innovation 6: 33-46.

Manoliadis, O.; Tsolas, I.; Nakou, A. 2006. Sustainable construction and drivers of change in Greece: a delphi study, Construction Management and Economics 24: 113-120.

http://dx.doi.org/10.1080/01446190500204804 
Myers, D. 2005. A review of construction companies' attitudes to sustainability, Construction Management and Economics 23: 781-785. http://dx.doi.org/10.1080/01446190500184360

Newbold, J. 2006. Chile's environmental momentum: ISO 14001 and the large-scale mining industry - case studies from the state and private sector, Journal of Cleaner Production 14: 248-261. http://dx.doi.org/10.1016/j.jclepro.2004.05.010

Ofori, G. 2007. Construction in developing countries, Construction Management and Economics 25: 1-6. http://dx.doi.org/10.1080/01446190601114134

Pitt, M.; Tucker, M.; Riley, M.; Longden, J. 2009. Towards sustainable construction: promotion and best practices, Construction Innovation: Information, Process, Management 9: 201-224.

Robichaud, L. B.; Anantatmula, V. S. 2011. Greening project management practices for sustainable construction, Journal of Management in Engineering 27: 48-57. http://dx.doi.org/10.1061/(ASCE)ME.1943-5479.0000030

Serpell, A.; Kort, J. 2006. Sustainable construction in Chile: a diagnosis, in CIB W107 Construction in Developing Construction International Symposium "Construction in Developing Economies: New Issues and Challenges", 18-20 January 2006, Santiago, Chile.

Shafii, F.; Ali, Z. A.; Othman, M. Z. 2006. Achieving sustainable construction in the developing countries of Southeast Asia, in 6th Asia-Pacific Structural Engineering and Construction Conference, 2006, Kuala Lumpur, Malaysia.

Shen, L.-Y.; Tam, V. W. Y.; Tam, L.; Ji, Y.-B. 2010. Project feasibility study: the key to successful implementation of sustainable and socially responsible construction management practice, Journal of Cleaner Production 18: 254-259. http://dx.doi.org/10.1016/j.jclepro.2009.10.014

Shi, Q.; Zuo, J.; Huang, R.; Huang, J.; Pullen, S. 2013. Identifying the critical factors for green construction - an empirical study in China, Habitat International 40: 1-8. http://dx.doi.org/10.1016/j.habitatint.2013.01.003

Son, H.; Kim, C.; Chong, W. K.; Chou, J.-S. 2011. Implementing sustainable development in the construction industry: constructors' perspectives in the US and Korea, Sustainable Development 19(5): 337-347. http://dx.doi.org/10.1002/sd.442

Tan, Y.; Shen, L.; Yao, H. 2011. Sustainable construction practice and contractors' competitiveness: a preliminary study, Habitat International 35: 225-230. http://dx.doi.org/10.1016/j.habitatint.2010.09.008

Turin, D. A. 1973. The construction industry: its economic significance and its role in development. Building Economic Reserach Unit, University College of London.

Van Bueren, E.; De Jong, J. 2007. Establishing sustainability: policy successes and failures, Building Research \& Information 35: 543-556. http://dx.doi.org/10.1080/09613210701203874

Yudelson, J. 2009. Green building through integrated design. New York: McGraw-Hill Companies, Inc.

Zainul-Abidin, N. 2010. Investigating the awareness and application of sustainable construction concept by Malaysian developers, Habitat International 34: 421-426.

http://dx.doi.org/10.1016/j.habitatint.2009.11.011 


\section{APPENDIX}

This appendix shows some of the questions included in the survey that were analysed in this paper.

Q1: What is the percentage of projects carried out in the last 3 years where your company has implemented actions to reduce or prevent the following aspects?

\begin{tabular}{|l|l|l|l|l|l|l|l|}
\hline \multicolumn{2}{|l|}{ Aspect: } & N.A. $0 \%$ & $25 \%$ & $50 \%$ & $75 \%$ & $100 \%$ \\
\hline a. & Solid waste materials & & & & & & \\
\hline b. & Water use & & & & & & \\
\hline c. & Danger waste materials & & & & & & \\
\hline d. & Dust emissions & & & & & & \\
\hline e. & Chemical liquids and materials & & & & & & \\
\hline f. & Noise & & & & & & \\
\hline g. & Energy use & & & & & & \\
\hline h. & Other, specify & & & & & & \\
\hline
\end{tabular}

Q3: What has been the level of influence of the following aspects to promote the implementation of SC practices in your company?

\begin{tabular}{|c|c|c|c|c|c|c|}
\hline & Aspect: & $\begin{array}{c}\text { No influence } \\
0 \%\end{array}$ & $\leftarrow$ & $50 \%$ & $\overrightarrow{75 \%}$ & $\begin{array}{c}\text { Large influence } \\
100 \%\end{array}$ \\
\hline a. & Client demand & & & & & \\
\hline b. & Cost reduction & & & & & \\
\hline c. & $\begin{array}{l}\text { Company's sustainable } \\
\text { awareness }\end{array}$ & & & & & \\
\hline d. & Suppliers & & & & & \\
\hline e. & Regulations & & & & & \\
\hline f. & Corporate image & & & & & \\
\hline g. & Market differenciation & & & & & \\
\hline h. & Other, specify & & & & & \\
\hline
\end{tabular}

Q7: Evaluate the level of awareness on sustainability of you construction company.

\begin{tabular}{|c|c|c|c|c|}
\hline $\begin{array}{c}\text { No aware } \\
0 \%\end{array}$ & $25 \%$ & $50 \%$ & $75 \%$ & $100 \%$ \\
\hline & & & & \\
\hline
\end{tabular}

Q6: In your opinion, what is the level of knowledge

Q21: What is theinfluence of the following governmental on SC of the following construction industry stakeholders?

\begin{tabular}{|c|c|c|c|c|c|c|}
\hline \multirow{2}{*}{\multicolumn{2}{|c|}{ Aspect: }} & \multicolumn{4}{|c|}{ No knowledge $\longleftarrow$} & \multirow{2}{*}{$\begin{array}{c}\text { Knowledgeable } \\
100 \%\end{array}$} \\
\hline & & $0 \%$ & $25 \%$ & $50 \%$ & $75 \%$ & \\
\hline a. & Designers & & & & & \\
\hline b. & Suppliers & & & & & \\
\hline c. & Contractors & & & & & \\
\hline d. & Owners & & & & & \\
\hline e. & $\begin{array}{l}\text { Council planning } \\
\text { departments }\end{array}$ & & & & & \\
\hline f. & Developers & & & & & \\
\hline
\end{tabular}

Q18: What are the financial incentives to promote SC practices that could be better implemented? Use 1 for the most important incentive and 2 for the second more important incentive.

\begin{tabular}{|l|l|l|}
\hline \multicolumn{2}{|l|}{ Financial incentive } & \\
\hline a. & Subvention of green building products & \\
\hline b. & Real state tax reduction & \\
\hline c. & Company's tax reduction according to SC investment & \\
\hline d. & $\begin{array}{l}\text { Rise of the maximum built surface allowed by planning } \\
\text { departments }\end{array}$ & \\
\hline
\end{tabular}
barriers on preventing the implementation of SC practices in your company?

\begin{tabular}{|c|c|c|c|c|c|c|}
\hline & $\begin{array}{l}\text { Governmental } \\
\text { barriers }\end{array}$ & $\begin{array}{c}\text { No influence } \\
0 \%\end{array}$ & $\longleftarrow$ & $50 \%$ & $\overrightarrow{75 \%}$ & $\begin{array}{l}\text { Large influence } \\
\quad 100 \%\end{array}$ \\
\hline a. & $\begin{array}{l}\text { Lack of public } \\
\text { information about SC } \\
\text { policies/regulations }\end{array}$ & & & & & \\
\hline b. & $\begin{array}{l}\text { Lack of financial } \\
\text { incentives }\end{array}$ & & & & & \\
\hline c. & $\begin{array}{l}\text { Not adequate } \\
\text { environmental } \\
\text { policies }\end{array}$ & & & & & \\
\hline d. & $\begin{array}{l}\text { Unefficient } \\
\text { environmental } \\
\text { policies }\end{array}$ & & & & & \\
\hline e. & $\begin{array}{l}\text { Governmental } \\
\text { bureaucracy }\end{array}$ & & & & & \\
\hline f. & $\begin{array}{l}\text { Discrepancy between } \\
\text { national and local } \\
\text { governmental } \\
\text { policies/regulations }\end{array}$ & & & & & \\
\hline h. & Other, specify & & & & & \\
\hline
\end{tabular}


Alfredo SERPELL is a Professor in the Department of Construction Engineering and Management at the Pontificia Universidad Católica de Chile. He holds a civil engineering degree from Catholic University and MSc and PhD degrees from the University of Texas at Austin, USA. Professor Serpell is member and the Coordinator of the CIB Working Commission 107 Construction in Developing Countries and an active member of the Project Management Institute, American Society for Quality and American Association for Cost Engineering International. He is very active in research on construction and project management topics.

Jorge KORT received his Bachelor and MSc degrees in civil engineering from Pontificia Universidad Católica de Chile.

Sergio VERA is an Assistant Professor in the Department of Construction Engineering and Management at the Pontificia Universidad Católica de Chile. He received his Bachelor and MSc degrees in civil engineering from Pontificia Universidad Católica de Chile and his $\mathrm{PhD}$ in building engineering from Concordia University (Montreal, Canada). His research interests are sustainable construction; sustainable building design; whole-building heat, air and moisture response; and modelling indoor air movement via CFD. 